\title{
EDITORIALS
}

\section{LET THERE BE LIGHT?}

Light, near ultra-violet light, blue light, may - they say - harm our corneae,${ }^{1}$ lenses ${ }^{2}$ and retinae, ${ }^{3}$ and our eyes in general. ${ }^{4}$ Much of the evidence is epidemiological and, therefore, correlative. Dolin ${ }^{5}$ has listed an impressive array of criteria showing the transition between correlation and (presumed) causality. At the end of the day, however, causality can only be established with some probability of success if the links between risk factor and risk are forged in terms of one or more mechanisms capable of explaining them. Presbyopia illustrates this.

All eyes become presbyopic; lenses yellow with age; lenses harden with age; ergo lenses develop cataracts. No mechanism linking these calendar events is advanced, but the sequence is implied to be self-explanatory.

However, the first principle governing interaction between tissues and radiation is that the former has to absorb the latter: there can be no effect without absorption. Thus, when Dolin ${ }^{5}$ assesses the evidence regarding the interaction between the prevalence of cortical and posterior subcapsular cataracts and the exposure to solar radiation, and notes that nuclear cataract cannot be linked to radiation, we face an extraordinary paradox. It is the nucleus that is coloured, and more so progressively as we age, ${ }^{6}$ yet it appears to be unaffected by radiation even though it absorbs it on a colossal scale. Conversely, the locus of the absorption of ultra-violet radiation said to generate cortical and posterior subcapsular opacities is unspecified. Although mechanisms describing possible aetiologies of cataract, for example in terms of oxygen toxicity, have been postulated, the testable specific pathway showing

absorption of UV $\rightarrow$ molecular damage $\rightarrow$ breakdown of repair processes $\rightarrow$ irreversible damage $\rightarrow$ opacities impairing vision

remains to be established.

In hot competition with the radiational hypothesis of the aetiology of cataract, comparisons between the biochemical make-up of lenses from the Indian sub-continent and the neighbourhood of Oxford, respectively, have led Harding and Rixon ${ }^{7}$ to explore the possibility that a correlate with high environmental temperature other than large dosages of (ultra-violet) light may explain the high prevalence of unspecified cataract in those regions. Dehydrational crises have been implicated, ${ }^{8}$ but the precise links remain to be elucidated.

However, even on the epidemiological level, there appear to exist problems, for example for the link between ultra-violet radiation and cortical cataract. Why is this type of cataract characteristic of negroid as distinct from Indian Africans? Why do indigenous Britons of Afro-Caribbean descent present with it earlier than is true of Caucasian patients? May it not be that evolutionary traits provide powerful confounding factors? Conversely, why do Afro-Caribbeans present relatively rarely with posterior subcapsular cataract, and why is there a statistically highly significant inverse relation between the relative prevalence of cortical cataract and the mixed nucleo-posterior subcapsular type ${ }^{9}$ It would seem that, while even LOCS III is too detailed for use in extensive epidemiological studies, and the unambiguous diagnosis of nuclear cataract is still subject to discussion, attention to types rather than just impairment of vision will be needed for the influence of environmental factors - including radiation - to be fully assessed.

In many ways, some of the above problems are found to be reflected in connection with potential radiational hazards to the retina. Epidemiologically, some doubt appears to exist as regards the existence of a link between exposure to sunlight and the risk of age-related maculopathies, ${ }^{10,11}$ even though protection during later life appears to offer an alleviation of such a risk as may exist.

Inferential conclusions followed the publication of the work by Wing et al., ${ }^{12}$ who found that the (alleged) age-pigment lipofuscin accumulates in the retinal pigment epithelium largely during the first two decades of life. A plateau extending for some 30 years is then followed by a resumption of pigment accumulation. Although no one has so far produced an action spectrum for this effect (which has been confirmed), several authors have 
suggested that the early branch may be due to the effect of (ultra-violet) radiation, which the young lens transmits with relative ease. ${ }^{13}$ The later part has been ascribed to a failure on the part of the retinal pigment epithelium to assimilate retinal debris ${ }^{14}$ although light has also been implicated with a modicum of quantitative support. ${ }^{15}$ As is true of the lens, the responsible site of the absorption of radiation has not so far been identified, thereby hindering the evaluation of a credible hypothesis.

Notwithstanding this obstacle, Simons ${ }^{16}$ has produced an elaboration of the original tentative suggestions which encompasses alleged hazards stemming from our exposure to fluorescent light. Sunlight and fluorescent light expose us to potentially noxious radiation for 16-18 hours of our waking time. Although he mentions the biphasic accumulation of lipofuscin, without explaining the secondary rise, he overlooks the possibility that it may not be linked to light at all. A similarly biphasic accumulation of lipofuscin takes place in the human sympathetic ganglia. ${ }^{17}$ Moreover, Mann and Yates ${ }^{18}$ have linked different amounts and rates of accumulation of lipofuscin in British and Sri Lankan brains with different ingestion rates of lipids. We should not assume that American data necessarily represent the Truth for all mankind as regards the effect of radiation on the eye or anything else: they may do no more than reflect dietary peculiarities of the subjects studied.

ROBERT WeALE

\section{References}

1. Coroneo MT. Albedo concentration in the anterior eye: a phenomenon that locates some solar diseases. Ophthalmic Surg 1990;21:60-6.

2. Young RW. Age-related cataract. Oxford: Oxford University Press, 1991.

3. Miller D, editor. Clinical light damage to the eye. Berlin, Springer, 1987.

4. Amalric P, Mur J, Santucci G. Oeil et lumière. Bull Soc Ophtal France. Special Report, 1990.

5. Dolin PJ. Ultraviolet radiation and cataract: a review of the epidemiological evidence. Br J Ophthalmol 1994;78:478-82.

6. Mellerio J. Yellowing of the human lens: nuclear and cortical contributions. Vision Res 1989;27:1581-7.

7. Harding JJ, Rixon KC. Carbamylation of lens proteins: a possible factor in cataractogenesis in some tropical countries. Exp Eye Res 1980;31:567-71.

8. Minassian DC, Mehra V, Jones, BR. Dehydrational crises from severe diarrhoea or heatstroke and risk of cataract. Lancet 1984;1:751-3.

9. Weale R. Interethnic risk ratios for different types of cataract. Montpellier: Proc JERMOV, 1994.

10. West SK, Rosenthal FS, Bressler NM, Bressler SB, Munoz B, Fine SL, Taylor HR. Exposure to sunlight and other risk factors for age-related macular degeneration. Arch Ophthalmol 1989;107:875-9.

11. Taylor HR, West S, Munoz B, Rosenthal FS, Bressler SB, Bressler NM. The long-term effects of visible light on the eye. Arch Ophthalmol 1992;110:99-104.

12. Wing GL, Blanchard GC, Weiter JJ. The topography and age relationship of lipofuscin concentration in the retinal epithelium. Invest Ophthalmol Vis Sci 1978;17:601-7.

13. Weale RA. Age and the transmittance of the human crystalline lens. J Physiol (Lond) 1988;395:577-87.

14. Dorey CA, Wu G, Ebenstein D, Garsd A, Weiter JJ. Cell loss in the aging retina. Invest Ophthalmol Vis Sci 1989;30:1691-9.

15. Weale RA. Do years or quanta age the retina? Photochem Photobiol 1989;50:429-38.

16. Simons K. Artificial light and early-life exposure in age-related macular degeneration and in cataractogenic phototoxicity. Arch Ophthalmol 1993;111:297-8.

17. Koistinaho J, Sorraniemi M, Alho H, Hervonen A. Microspectrofluorometric quantitation of autofluorescent lipopigment in the human sympathetic ganglia. Mech Ageing Dev 1986;37:79-89.

18. Mann DMA, Yates PO. Accumulation of lipoprotein pigments in nerve cells of British and Sri Lankan nationals. Mech Ageing Dev 1982;18:151-8. 